\title{
THE MODE OF ACTION OF PYRITHIAMINE AS AN INDUCTOR OF THIAMINE DEFICIENCY*
}

\author{
J. C. KOEDAM \\ Laboratory for Physiological Chemistry, The University, Utrecht (The Netherlands)
}

According to a theory proposed by Woolley AND MERRIFIELD', thiamine would not only display its physiological action in the animal body through its conversion to thiamine pyrophosphate (TPP $\left.{ }^{\star}\right)$, which acts as a prosthetic group of various enzymes, but in the brain it would moreover have a second function, inhibited by the antagonist pyrithiamine and not requiring preliminary phosphorylation to TPP. Impairment of this second function in particular might be the cause of polyneuritic symptoms observed in thiamine deficiency.

This theory was brought forward to account for experiments in which a large dose of pyrithiamine, given to mice receiving $2 \mu \mathrm{g}$ thiamine daily, provoked the characteristic symptoms of polyneuritis without a concomitant decrease of TPP in the liver. Moreover, WoOLLEY ${ }^{2}$ had observed that although pyrithiamine can inhibit the synthesis of TPP from thiamine by chicken blood in vitro, this requires large amounts of the antivitamin. The concentration of pyrithiamine in the tissues of the afore-mentioned mice was therefore considered to be too low to inhibit phosphorylation of thiamine in vivo.

In the course of a number of years considerable experience has been gained in this laboratory regarding the relationship between disturbances in thiamine metabolism and the occurrence of clinical symptoms and death in a deficiency induced by withholding the vitamin from the diet. In the light of this experience we wondered whether the present concepts regarding the physiological role of thiamine, acting through TPP, would not be adequate to explain also the phenomena observed in thiamine deficiency induced by administration of pyrithiamine. In that case there would be no need for a new additional hypothesis concerning the physiological action of thiamine.

To elucidate this point, and also to be in a better position to compare the deficiency diseases induced in these two different ways, a more detailed investigation was undertaken of the thiamine deficiency provoked by pyrithiamine.

The pigeon was chosen as a test animal for the following reasons: (a) considerable experience has been gained regarding the response of pigeons to diets lacking thiamine; (b) the amount of food consumed has a profound influence on the development of the deficiency and the pigeon can be forcibly fed with great ease.

The investigation presented here has borne out that on the whole thiamine deficiency provoked by pyrithiamine closely resembles that induced by withholding the vitamin.

\footnotetext{
* This work forms part of investigations on thiamine metabolism by H. G. K. WESTENBRINK and co-workers.

** Abbreviations used: T, thiamine; P'T, pyrithiamine; OT, oxythiamine; Tr'P, thiaminc pyrophosphate; PTPP, pyrithiamine pyrophosphate; OTPP, oxythiamine pyrophosphate: ATP, adenosine triphosphate.
} 


\section{MATERIALS AND METHODS}

Thiamine-HCl was purchased from F. Hoffman-La Roche A. G., Basle, Switzerland; pyrithiamineHBr from the Nutritional Biochemicals Corporation, Cleveland, Ohio, U.S.A. In some experiments another preparation of pyrithiamine was used, for which we are greatly indebted to Dr. K. FoLKERS of Merck Inc., Rahway, N. J., U.S.A. Oxythiamine was kindly supplied to us by Dr. J. LENS, Director of Organon N.V., Oss, The Netherlands.

TPP was determined according to WESTENBRINK ANID STEYN-PARVF́3 ${ }^{3}$. To check the possibility that values found for TPP in tissuc extracts of pigeons given pyrithiamine might be too low owing to an inhibition of the reaction of TPP and yeast apocarboxylase by pyrithiamine pyrophosphate in the extracts, known amounts of TPP were added to extracts of tissues of normal pigeons, pigeons on a thiamine-free diet and pigeons fed pyrithiamine and thiamine. In all cases the recoveries were the same (Table I). Indeed, the recovery was never complete and decreased with increasing amounts of extract. So tissue extracts evidently do contain some kind of inhibitor of yeast carboxylase, but this has nothing to do with pyrithiamine or its derivatives *.

\section{TABLE I}

RECOVERY OF KNOWN AMOUNTS OF THIAMINE PYROPHOSPHATE, ADDED TO TISSUE EXTRACTS

Group I : pigeons dead as a result of administration of pyrithiamine. Group I I normal or thiaminedeficient pigeons. Average values. Standard errors of the mean indicated between parentheses.

$\begin{array}{lccc}\text { Group } & \text { No. of detns, } & \text { TPP added } & \% \text { recovery } \\ \text { I } & 20 & 5 \text { or Io } \mu \mathrm{g} & 85(3) \\ \text { II } & 22 & 5 \text { or Io } \mu \mathrm{g} & 86(3)\end{array}$

Acetoin was cletermined according to WESTERFELD ${ }^{4}$ and pyruvate according to liRIEIEMANN AND HAUGEN". Thiaminokinase was prepared from rat liver, following the method of LEUTHARDT AND Nielsen". The fraction called by them "précipité HCl" was used.

The basic food given each day by stomach tube consisted of $18 \mathrm{~g}$ glucose, $2 \mathrm{~g}$ commercial casein (containing $0.6 \mu \mathrm{g}$ of $\mathrm{T}$ ) $0.3 \mathrm{~g}$ of the salt mixture according to JANSEN AND IVESTENBRINK and $85 \mathrm{mg}$ of the vitamin mixture of GRUBER ${ }^{8}$.

All feeding experiments to be rlescribed wero preceded by an "initial period" in which the pigeons were forcibly fed during to days with the basic food, supplemented with oo $/ \mathrm{g} \mathrm{T}$.

The pigeons always received their food at + p.m. and were killed at about ro a.m.

The birds were killed by decapitation. $10 \%$ bomogenates in ice-cold o. $1 M$ phosphate buffer, pH 6.2, supplemented with $0.0013 .1 / \mathrm{Mn}\left(\mathrm{I}_{2}\right.$ were made from breast muscle (m. pect. major), heart muscle (left ventricle), liver and brain (cerebrum) in a Potter-Elvehjem homogenizer. Part of the homogenates was used for the determination of TI'I'. Another part was employed to measure the anacrobic pyruvate consumption and acetoin formation as follows: $2 \mathrm{ml}$ samples were pipetted into the main compartment of Warburg flasks, already containing cither o. $1 \mathrm{ml}$ o. I .M phosphate buffer, $\mathrm{pH} 6.2$, or the same volume of buffer with $10 \mu \mathrm{g}$ l P P. After gassing with pure nitrogen and equilibrating for 15 minutes in the water bath of $37^{\circ} \mathrm{I}$. $1 \mathrm{mg}(10 \mu$ moles) sodium pyruvate, clissolved in $0.2 \mathrm{ml}$ of the same phosphate buffer, was tipped in from the side bulb. After one hour the reaction was stopper by adding successively $\mathrm{I} \mathrm{ml}$ to \% trichloroacetic acid and $4 \mathrm{ml}$ water. After standing for alout 2 hours at 4 and centrifuging, acetoin and pyruvate were determined in the clear supernatants. Controls were deproteinized immediately after the addition of pyruvate. Significance tests were carried out by calculating $P$-values according to Wilcoxos?.

\section{EXPERIMENTS IND RESULTS}

\section{Feeding experiments}

I. In the first expcriment 8 groups of 9 animals of the same average body weight were passed through the initial period, after which a control group (C) was killed and examined. Then the basic food plus $\mathrm{T}$ of six of the remaining groups

* Recent experiments with chromatographically purified pyrithiamine pyrophosphate have confirmed that this substance has no inhibitory effect upon the determination of thiamine pyrophosphate up to a concentration of a hundred times that of TPP.

lieferences p. 344 . 
$\left(A_{1}, A_{2}, A_{4}, A_{8}, A_{12}, A_{x}\right)$ was supplemented with $623 \mu \mathrm{g}$ PT daily (molar ratio $\mathrm{PT}: \mathrm{T}=5: \mathrm{I}$ ), while a second control group $\mathrm{C}_{x}$ remained on the basic diet plus $T$.

Group $A_{1}$ was killed and examined after $I$ day, group $A_{2}$ after 2 days of PT administration, etc. Pigeons of these groups which died were discarded. The pigeons of group $\mathrm{A}_{x}$ were either examined when they showed severe symptoms, i.e. opisthotonus, rolling backwards with vigorous flapping of the wings and sometimes emphrosthotonus and leg weakness, or immediately after a sudden death without distinct symptoms of polyneuritis*. Opisthotonus was seen in 6 animals of this group. Group $\mathrm{C}_{x}$ was killed 48 days after the other groups received their first dose of PT.

The results of this experiment are assembled in Tables II and III. The percentual changes in time of TPP contents and enzyme activity relative to the control group (C) can be seen in Figs. I, 2 and 3.

TABLE II

THIAMINE PYROPHOSPHATE CONTENT OF SOME TISSUES OF PIGEONS AFTER FEEDING PYRITHIAMINE Groups $C$ and $C_{x}$ : controls, Ioo $\mu \mathrm{g}$ thiamine daily. Groups $A_{4}, A_{8}, A_{12}, A_{x}:$ Ioo $\mu g$ thiamine and $623 \mu \mathrm{g}$ pyrithiamine daily. Average values. Standard errors of the mean indicated between parentheses.

\begin{tabular}{|c|c|c|c|c|c|c|c|}
\hline \multirow{2}{*}{ Group } & \multirow{2}{*}{$\begin{array}{c}\text { No. of } \\
\text { animals }\end{array}$} & \multirow{2}{*}{$\begin{array}{c}\text { Days on } \\
T \text { only }\end{array}$} & \multirow{2}{*}{$\begin{array}{l}\text { Day's an } \\
T+P T\end{array}$} & \multicolumn{4}{|c|}{$T P P(\mu g / g)$} \\
\hline & & & & Breasl & Liver & Heart & Brain \\
\hline $\mathrm{C}$ & 7 & Io & o & $5.67(0.25)$ & $5.49\left(0.4^{6}\right)$ & $4.81(0.3 I)$ & $2.70(0.18)$ \\
\hline $\mathrm{C}_{x}$ & 7 & $10+4^{8}$ & $o$ & $5.54(0.20)$ & 4. I0 (0.16) & $4.73(0.20)$ & $2.5 \mathrm{I}(0.09)$ \\
\hline $\mathrm{A}_{4}$ & 7 & 10 & 4 & $3.93(0.29)$ & i. $.73(0.20)$ & $2.06(0.20)$ & 1. I $7(0.09)$ \\
\hline $\mathrm{A}_{8}$ & 7 & 10 & 8 & 2.53 (O.II) & 1.43 (0.10) & I. I $5(0.09)$ & $0.89(0.07)$ \\
\hline$A_{12}^{\circ}$ & 7 & 10 & 12 & $2.33(0.13)$ & $1.36(0.14)$ & $1.21(0.13)$ & $0.80(0.06)$ \\
\hline $\mathbf{A}_{x}^{2}$ & 7 & Io & $\begin{array}{c}9-64 \\
(\text { av. } 27)\end{array}$ & $1.96(0.14)$ & I. $50(0.15)$ & $1.09(0.06)$ & $0.73(0.08)$ \\
\hline
\end{tabular}

Fig. I. Percentual decrease of thiamine pyrophosphate in various tissues of the pigeon after feeding pyrithiamine. Abscissa: number of days pyrithiamine was given (last point $=$ mean survival time). Ordinate: TPP content in percentage of control value (mean values indicated only).

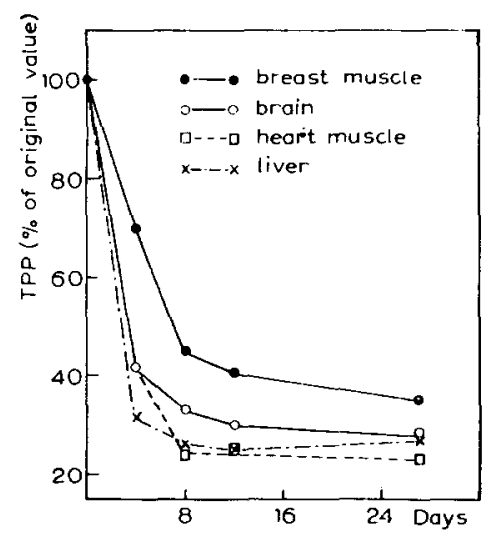

In the first few days the decrease of TPP in the tissues examined is very rapid. After only 4 days the values are significantly lower than in the controls ( $P$-values :o.ooI). After 8 days between 24 and $45 \%$ of the original amount remains (Fig. I). The further decrease is negligible or nil.

\footnotetext{
* When the experiment was discontinued after 64 days, one animal of this group was still alive and apparently in a reasonable condition. It was then killed. The values agreed with those found for the other pigeons and were also used in calculating the mean values in Tables II and III.
} 
Breast and heart muscle were the only tissues examined for pyruvate consumption and acetoin production. In both tissues the pyruvate consumed is partly converted into acetoin and partly disappears through dismutation (2 pyruvate $\rightarrow$ I lactate $+\mathrm{I}$ acetate $+\mathrm{I} \mathrm{CO}_{2}$ ). In normal heart-muscle homogenates, however, the fraction of pyruvate transformed into acetoin is much smaller than in normal breastmuscle homogenates:

\begin{tabular}{|c|c|c|}
\hline Breast muscle: & $\begin{array}{l}\text { total pyruvate consumed } \\
\text { converted into acetoin } \\
\text { dismutation }\end{array}$ & $\begin{array}{l}2.36 \mu \text { moles } \\
\text { I. } 78 \mu \text { moles } \\
0.5^{8} \mu \text { moles }\end{array}$ \\
\hline$F$ & $\begin{array}{l}\text { total pyruvate consumed } \\
\text { converted into acetoin } \\
\text { dismutation }\end{array}$ & $\begin{array}{l}5.94 \mu \text { moles } \\
0.90 \mu \text { moles } \\
5.04 \mu \text { moles }\end{array}$ \\
\hline
\end{tabular}

From Table III and Figs. 2 and 3 it appears that in heart muscle acetoin formation is more sensitive to treatment of the pigeons with PT than the dismutation reaction. Acetoin formation has already practically stopped after 4 days. But as only a small fraction of the metabolized pyruvate is involved in acetoin formation, total pyruvate consumption is affected only very slightly by PT treatment.

In breast muscle, however, both acetoin production and pyruvate consumption have decreased to an equal extent after 4 days of pyrithiamine; they are then already significantly lower than in the controls ( $P$-values $\leqq 0.00 I)$.

TABLE III

ANAEROBIC CONSUMPTION OF PYRUVATE AND PRODUCTION OF ACETOIN BY TISSUES OF PIGEONS AFTER FEEDING PYRITHIAMINE

Same experiment as Table II, for details consult that table. Mean enzymic activity expressed in $\mu$ moles pyruvate (acetoin) $/ \mathrm{h} / 200 \mathrm{mg}$ tissue. $+\mathrm{TPP}=$ 10 $\mu \mathrm{g}$ TPP added to the homogenate in vitro. Groups $\mathrm{A}_{1}$ and $\mathrm{A}_{2}: 100 \mu \mathrm{g}$ thiamine $+623 \mu \mathrm{g}$ pyrithiamine for I and 2 days, respectively.

\begin{tabular}{|c|c|c|c|c|c|c|c|c|c|}
\hline \multirow{3}{*}{ Group } & \multirow{3}{*}{$\begin{array}{l}\text { No of } \\
\text { deins. }\end{array}$} & \multicolumn{4}{|c|}{ Breast muscle } & \multicolumn{4}{|c|}{ Heart muscle } \\
\hline & & \multicolumn{2}{|c|}{ Pyruvate consumption } & \multicolumn{2}{|c|}{ Aceloin production } & \multicolumn{2}{|c|}{ Pyruvate consumption } & \multicolumn{2}{|c|}{ Acetoin production } \\
\hline & & $-T P P$ & $+T P P$ & $-T P P$ & $+T P P$ & $-T P P$ & $+T P P$ & $-T P P$ & $+T P P$ \\
\hline $\mathrm{C}$ & 9 & $\begin{array}{c}2.36 \\
(0.15)\end{array}$ & $\begin{array}{c}3.08 \\
(0.13)\end{array}$ & $\begin{array}{c}0.89 \\
(0.06)\end{array}$ & $\begin{array}{c}\mathrm{I} .20 \\
(0.07)\end{array}$ & $\begin{array}{c}5.94 \\
(0.37)\end{array}$ & $\begin{array}{c}6.73 \\
(0.33)\end{array}$ & $\begin{array}{c}0.45 \\
(0.05)\end{array}$ & $\begin{array}{c}0.69 \\
(0.06)\end{array}$ \\
\hline $\mathrm{C}_{x}$ & 7 & $\begin{array}{c}2.84 \\
(0.10)\end{array}$ & $\begin{array}{c}3.63 \\
(0.14)\end{array}$ & $\begin{array}{c}1.07 \\
(0.04)\end{array}$ & $\begin{array}{c}1.47 \\
(0.04)\end{array}$ & $\begin{array}{c}5.07 \\
(0.42)\end{array}$ & $\begin{array}{c}5.79 \\
(0.42)\end{array}$ & $\begin{array}{c}0.47 \\
(0.02)\end{array}$ & $\begin{array}{c}0.73 \\
(0.02)\end{array}$ \\
\hline$A_{1}$ & 8 & - & - & - & - & - & $\longrightarrow$ & $\begin{array}{c}0.31 \\
(0.03)\end{array}$ & - \\
\hline $\mathbf{A}_{2}$ & 7 & - & - & - & - & - & - & $\begin{array}{c}0.11 \\
(0.01)\end{array}$ & - \\
\hline$A_{4}$ & 7 & $\begin{array}{c}1.30 \\
(0.12)\end{array}$ & $\begin{array}{c}2.54 \\
(0.16)\end{array}$ & $\begin{array}{c}0.51 \\
(0.04)\end{array}$ & $\begin{array}{c}\text { I.07 } \\
(0.05)\end{array}$ & $\begin{array}{c}5 \cdot 5 \mathrm{I} \\
(0.62)\end{array}$ & $\begin{array}{c}7.03 \\
(0.5 \mathrm{I})\end{array}$ & $\begin{array}{c}0.03 \\
(0.01)\end{array}$ & $\begin{array}{c}0.5 \mathrm{I} \\
(0.04)\end{array}$ \\
\hline$A_{8}$ & 7 & $\begin{array}{c}0.97 \\
(0.20)\end{array}$ & $\begin{array}{c}2.63 \\
(0.14)\end{array}$ & $\begin{array}{c}0.29 \\
(0.03)\end{array}$ & $\begin{array}{c}0.96 \\
(0.05)\end{array}$ & $\begin{array}{r}5.16 \\
(0.59)\end{array}$ & $\begin{array}{c}6.87 \\
(0.67)\end{array}$ & $\begin{array}{c}0.01 \\
(0.01)\end{array}$ & $\begin{array}{c}0.39 \\
(0.06)\end{array}$ \\
\hline$A_{12}$ & 6 & $\begin{array}{c}0.85 \\
(0.25)\end{array}$ & $\begin{array}{c}2.77 \\
(0.15)\end{array}$ & $\begin{array}{c}0.22 \\
(0.03)\end{array}$ & $\begin{array}{c}0.99 \\
(0.06)\end{array}$ & $\begin{array}{c}4.70 \\
(0.48)\end{array}$ & $\begin{array}{c}6.93 \\
(0.49)\end{array}$ & $\begin{array}{c}0.03 \\
(0.01)\end{array}$ & $\begin{array}{c}0.4^{8} \\
(0.07)\end{array}$ \\
\hline $\mathbf{A}_{x}$ & 6 & $\begin{array}{c}0.88 \\
(0.25)\end{array}$ & $\begin{array}{c}3.16 \\
(0.30)\end{array}$ & $\begin{array}{c}0.09 \\
(0.03)\end{array}$ & $\begin{array}{c}0.97 \\
(0.05)\end{array}$ & $\begin{array}{c}4.22 \\
(0.5 \mathrm{I})\end{array}$ & $\begin{array}{c}6.42 \\
(0.76)\end{array}$ & $\begin{array}{r}-0.02 \\
(0.01)\end{array}$ & $\begin{array}{c}0.43 \\
(0.07)\end{array}$ \\
\hline
\end{tabular}

The control group $C_{x}$ shows that if the administration of PT is omitted the TPP contents as well as the enzyme activity of the tissues studied remain at the level found at the end of the initial feeding period. Thus the prolonged feeding of the animals with 


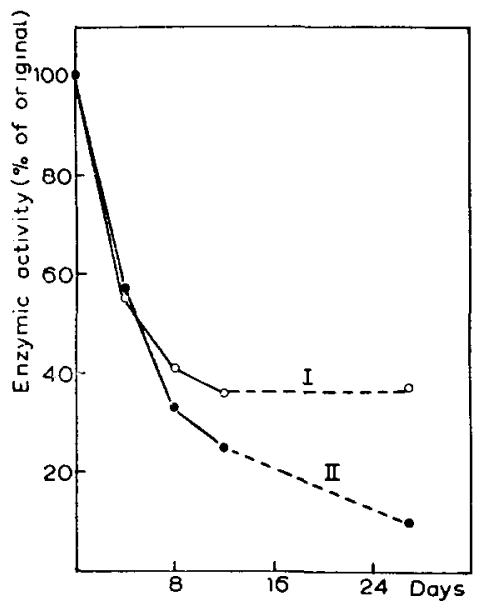

Fig. 2. Influence of feeding pyrithiamine on anaerobic pyruvate consumption and acetoin production by homogenates of pigeon breast muscle. Abscissa: number of days pyrithiamine was given (last point: mean survival time).

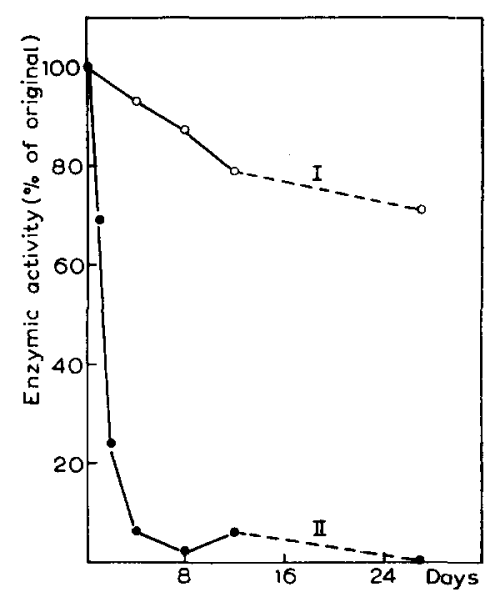

Fig. 3. Influence of feeding pyrithiamine on anaerobic pyruvate consumption and acetoin production by homogenates of pigeon heart muscle. Details as in Fig. 2 .

Ordinate: Pyruvate consumption or acetoin production in percentage of control value (mean values indicated only). I: pyruvate consumption. II : acetoin production.

our synthetic food by stomach tube does not harm the animals in these respects.

Finally, Table III shows that by adding TPP in vitro total pyruvate utilization is restored completely; acetoin formation is restored to about $80 \%$ in breast-muscle homogenates and to 60 to $70 \%$ of normal in heart-muscle homogenates.

Generally speaking, these observations on TPP contents, pyruvate consumption and acetoin production closely resemble those made by MONFOORT ${ }^{10}$ with pigeons on a thiamine-deficient diet.

2. The second experiment was set up in order to compare the short-term effects of giving pyrithiamine + thiamine and withholding thiamine from the diet. 26 pigeons were divided into 3 groups. The animals of group $C^{\prime}$ (controls) were killed immediately at the end of the initial period; the animals of group $\mathrm{A}_{4}^{\prime}$ received the basic food, supplemented with Ioo $\mu \mathrm{gT}$ and $623 \mu \mathrm{g}$ PT, from that time onward, while the pigeons of group $\mathrm{D}_{4}$ were fed the basic food without thiamine. The animals of the groups $\mathrm{A}_{4}{ }^{\prime}$ and $\mathrm{D}_{4}$ were killed after 4 days and TPP was determined in a number of organs (Table IV).

It appears that the decrease of the TPP contents after administration of the antivitamin is more rapid than that which results from withholding the vitamin. In brain the difference is greatest.

3. In the third experiment a comparison was made of the TPP contents in heart muscle and brain at death, following either the feeding of pyrithiamine + thiamine or the withholding of thiamine from the diet. Two groups of pigeons $\left(A_{x}{ }^{\prime}\right.$ and $D_{x}$ ) received the same food as the animals of $A_{4}^{\prime}$ and $D_{4}$. The pigeons were killed when they could be expected to die within a few hours according to our experience; they thus lived a varying number of days.

The pigeons of group $\mathrm{D}_{x}$, not receiving $\mathrm{T}$ or PT, died after 12 to 29 days (av. I7 days). One animal developed slight opisthotonus before death; the others had leg weakness and were unable to stand. Three animals of group $A_{x}^{\prime}$ showed severe 


\section{TABLE IV}

COMPARISON OF SHORT-TERM EFFECTS OF FEEDING PYRITHIAMINE TOGETHER WITH THIAMINE, AND WITHHOLDING THIAMINE FROM THE DIET,

ON THE THIAMINE PYROPHOSPHATE CONTENT OF SOME TISSUES OF PIGEONS

Group $\mathrm{C}^{\prime}$ : controls, Ioo $\mu \mathrm{g}$ thiamine daily. Group $\mathrm{A}_{4}^{\prime}:$ I oo $\mu \mathrm{g}$ thiamine and $623 \mu \mathrm{g}$ pyrithiamine for 4 days. Group $\mathrm{D}_{4}$ : no thiamine or pyrithiamine for 4 days. Average values. Standard errors of the mean indicated between parentheses.

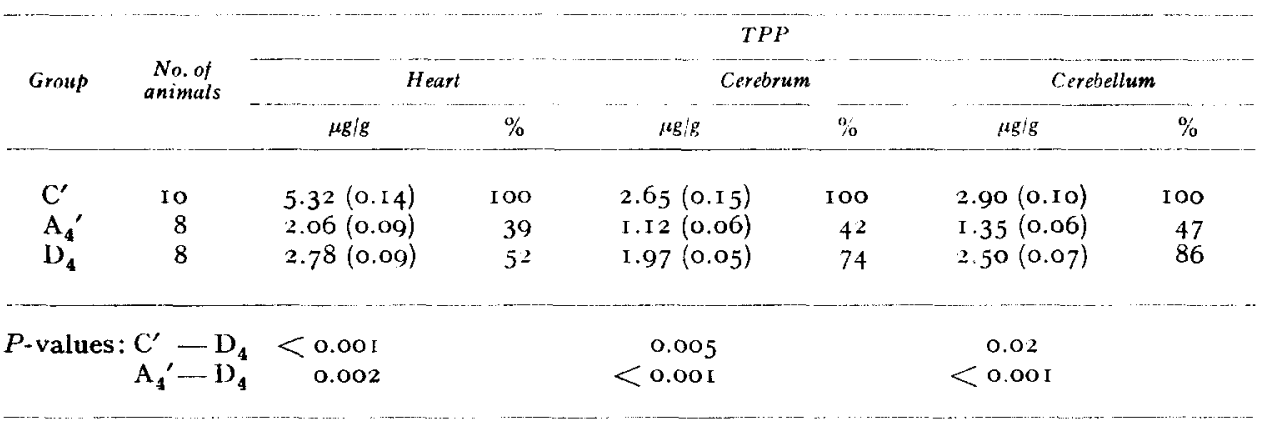

TABLE V

COMPARISON OF THIAMINE PYROPHOSPHATE IN HEART AND BRAIN OF PIGEONS AT DEATH AFTER FEEDING PYRITHIAMINE TOGETHER WITH THIAMINE, AND AFTER WITHHOLDING THIAMINE

Group $A_{x}{ }^{\prime}:$ roo $\mu \mathrm{g}$ thiamine and $623 \mu \mathrm{g}$ pyrithiamine daily. Group $\mathrm{D}_{2}$ : no thiamine or pyrithiamine. Average values. Stanclard errors of the mean indicated between parentheses.

\begin{tabular}{|c|c|c|c|c|c|}
\hline \multirow{2}{*}{ Group } & \multirow{2}{*}{$\begin{array}{c}\text { No.of } \\
\text { animils }\end{array}$} & \multirow{2}{*}{$\begin{array}{c}\text { Ancrage } \\
\text { swrvival time } \\
\text { (days) }\end{array}$} & \multicolumn{3}{|c|}{$T P P(\mu g, g)$} \\
\hline & & & Heilut & Cerebrum & Cerebellum \\
\hline $\mathrm{A}_{x^{\prime}}$ & 9 & $>34$ & $1.07(0.08)$ & $0.76(0.04)$ & $0.75(0.05)$ \\
\hline $\mathrm{I}_{x}$ & 9 & 17 & $0.77(0.06)$ & $0.86(0.05)$ & I.OI $(0.06)$ \\
\hline \multicolumn{3}{|c|}{$P$-values: $\mathrm{A}_{x}{ }^{\prime}-\mathrm{D}_{x}$} & 0.02 & 0.07 & 0.01 \\
\hline
\end{tabular}

opisthotonus after II to $2 \mathrm{I}$ days and therefore were killed. One animal died after 20 days without having shown deficiency symptoms. The remaining 5 animals still seemed to be in good condition after $4 \mathrm{I}$ days, while their weight loss was only about $25 \mathrm{~g}$ in the mean. They were then given a fourfold amount of PT, together with the usual dose of $100 \mu \mathrm{g}$ T. The same or the following day (after a second dose of $2.5 \mathrm{mg}$ PT) all 5 pigeons developed severe opisthotonus, convulsions, etc., and were killed.

The TPP contents of the tissues of these last animals did not differ from those of the other animals of group $\mathrm{A}_{x}{ }^{\prime}$ and were therefore grouped together with these values (Table $\mathrm{V}$ ).

At death the amount of TPP remaining in heart muscle appears to be a little larger after administration of PT than after withholding $\mathrm{T}$, whereas this situation is reversed in the brain, particularly in the cerebellum.

4. The purpose of the fourth experiment was to see whether deficiency symptoms would appear more rapidly after feeding pyrithiamine only, and how frequent opisthotonus would then be. A group $\left(\mathrm{E}_{x}\right)$ of Io pigeons received the basic food, this time only supplemented with $623 \mu \mathrm{g}$ PT daily. After 4 days about half of the animals 
had already developed severe symptoms of deficiency. ro days after the first administration of PT the last animal of group $\mathrm{E}_{x}$ had to be killed, because of its poor condition. In total, 6 animals of this group had opisthotonus and convulsions for a longer or shorter period, usually followed after an hour or so by a condition of leg weakness and immobility. In the other animals only this last condition was seen, but opisthotonus may have preceded it and escaped our attention. TPP was again determined in heart and brain (Table VI).

\section{TABLE VI}

THIAMINE PYROPHOSPHATE IN HEART AND BRAIN OF PIGEONS AFTER FEEDING PYRITHIAMINE WITHOUT THIAMINE

Group $\mathrm{E}_{x}: 623 \mu \mathrm{g}$ pyrithiamine daily. Average values. Standard errors of the mean indicated between parentheses. P-values calculated from a comparison with data from experiment 3 (groups $A_{x}^{\prime}$ and $D_{x}$ )

\begin{tabular}{|c|c|c|c|c|c|}
\hline \multirow{2}{*}{ Group } & \multirow{2}{*}{$\begin{array}{l}\text { No.of } \\
\text { animals }\end{array}$} & \multirow{2}{*}{$\begin{array}{c}\text { Average } \\
\text { survival time } \\
\quad \text { (days) }\end{array}$} & \multicolumn{3}{|c|}{$T P P(\mu g g)$} \\
\hline & & & Heart & Cerebrum & Cerebellum \\
\hline $\mathrm{E}_{\boldsymbol{x}}$ & Io & 5 & $1.08(0.06)$ & $0.88(0.03)$ & $0.91(0.04)$ \\
\hline \multicolumn{3}{|c|}{$\begin{aligned} P \text {-values : } & \left.\mathrm{E}_{x}-1\right)_{t}, \\
& \mathrm{E}_{x}-\mathrm{A}_{x},\end{aligned}$} & $\begin{aligned} & 0.004 \\
> & 0.5\end{aligned}$ & $\begin{array}{l}>0.5 \\
0.02\end{array}$ & $\begin{array}{l}0.2 \\
0.01\end{array}$ \\
\hline
\end{tabular}

In the heart we find the same amount of TPP remaining at death as in the animals of group $\mathrm{A}_{x}{ }^{\prime}$; the TPP contents of the brain, however, are a little higher in $\mathrm{E}_{x}$ than in $\mathrm{A}_{x}^{\prime}$, although the symptoms were the same in both groups.

5. Two experiments were performed to get an impression of the effect of a single large dose of PT. In the first experiment, only acetoin formation in heart-muscle homogenates, determined at different intervals after administration of a dose of $2.5 \mathrm{mg}$ PT, was chosen as a measure to test the effect of this dose, for experiment I had shown that acetoin production in heart muscle decreases more rapidly than any of the other variables measured. Also, $2.5 \mathrm{mg}$ PT can almost completely suppress acetoin production in heart muscle, if divided into 4 equal doses and given on 4 successive days.

4 groups of pigeons received one dose of $2.5 \mathrm{mg}$ PT at the end of the initial period while the daily administration of $\mathrm{T}$ was continued. After $\mathrm{I}, 2,4$ and 8 days the animals of the groups $B_{1}, B_{2}, B_{4}$ and $B_{8}$ were killed and analysed. One animal died suddenly during the experiment without having shown deficiency symptoms. Fig. 4 gives the average production of acetoin by heart-muscle homogenates of the various groups. For a comparison, acetoin formation after feeding $623 \mu \mathrm{g}$ PT daily has been included (experiment I).

Immediately after feeding $2.5 \mathrm{mg}$ PT, the formation of acetoin appears to fall off rapidly, to be followed by a slow restoration. After 8 days the normal level has not quite been re-attained. The formation of acetoin 4 days after a single fourfold dose of PT is much higher than after 4 daily doses of $623 \mu \mathrm{g} \mathrm{PT}$.

6. The second experiment with a single large dose of PT was devised to investigate whether a larger amount of PT would not cause more permanent damage to the animals or even kill them. To test this, Io animals were given ro mg PT, after which References p. 344 . 


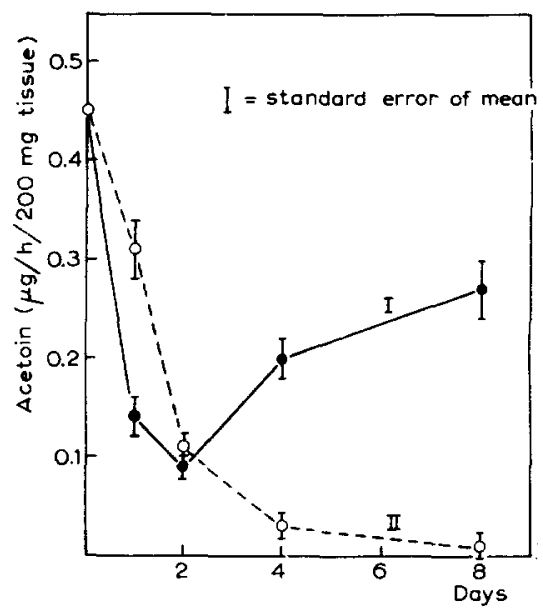

Fig. 4. Formation of acetoin by homogenates of pigeon heart muscle after giving pyrithiamine. I: one dose of $2.5 \mathrm{mg}$ pyrithiamine on day o. II: $623 \mu \mathrm{g}$ pyrithiamine daily. Each point is mean value of 6 to 8 determinations.

TABLE VII

THIAMINE PYROPHOSPHATE CONTENTS OF SOME TISSUES OF PIGEONS AFTER FEEDING A SINGLE LARGE DOSE OF PYRITHIAMINE

Group $\mathrm{B}_{x}$ : one dose of to $\mathrm{mg}$ pyrithiamine; killed 64 days later. Groups $\mathrm{C}_{1} \mathrm{C}_{x}, \mathrm{C}^{\prime}$ : control groups from experiments $I$ and 3 , included for comparison. Average values. Standard errors of the mean indicated between parentheses.

\begin{tabular}{|c|c|c|c|c|c|c|}
\hline \multirow{2}{*}{ Growp } & \multirow{2}{*}{$\begin{array}{c}\text { No. of } \\
\text { animals }\end{array}$} & \multicolumn{5}{|c|}{$T P P(\mu g / g)$} \\
\hline & & Breast & Liver & Heart & Cerebrum & Cerebellum \\
\hline $\mathbf{B}_{x}$ & 7 & $5.69(0.23)$ & $4.90(0.24)$ & $5.39(0.20)$ & $2.79(0.09)$ & $3.34(0.15)$ \\
\hline $\mathrm{C}^{2}$ & 9 & $5.67(0.25)$ & $5.49(0.46)$ & $4.8 \mathrm{I}(0.3 \mathrm{I})$ & $2.70(0.18)$ & - \\
\hline $\mathrm{C}_{x}$ & 7 & $5.54(0.20)$ & $4.10(0.16)$ & $4.73(0.20)$ & 2.5 I $(0.09)$ & - \\
\hline$C^{\prime}$ & Io & 5.72 (0.19) & $4.90(0.26)$ & $5.32(0.14)$ & $2.6_{5}(0.15)$ & $2.92(0.10)$ \\
\hline
\end{tabular}

they received each day the basic food and noo $\mu \mathrm{g} \mathrm{T}$ as usual. Two animals died after 28 and 47 days from unknown causes. The others remained in a good physical condition and were killed 64 days after the administration of the antivitamin. The TPP contents were then determined in 5 organs (Table VII). Control values from Tables II and III are included in Table VII. As far as the TPP contents of the investigated organs are concerned there is no permanent effect of the administration of ro $\mathrm{mg}$ PT to a pigeon.

\section{Inhibition of thiaminokinase by antivitamin}

From experiments by CERECEDo ${ }^{11}$ it seems likely that PT mainly acts through inhibition of the phosphorylation of thiamine. According to this author, thiaminokinase of animal origin would be inhibited much more strongly by pyrithiamine than by oxythiamine (OT). This might explain why the effect of OT in vivo is so much smaller than that of PT: after giving I or $2 \mathrm{mg}$ OT together with Ioo $\mu \mathrm{g} T$ daily to pigeons for 15 to 18 days, STEYN-PARVE ${ }^{12}$ found practically no decrease of TPP in 
brain and liver, while the contents had diminished by $42 \%$ and $20 \%$ respectively in heart and breast muscle.

To get more information on this point we have also tested the effect of PT and OT on the ability of partly purified liver thiaminokinase to phosphorylate thiamine. We found that PT indeed markedly inhibits the synthesis of TPP, while OT does not interfere at all under our test conditions, thus confirming the observations made by Cerecedo (Table VIII).

TABLE VIII

EFFECT OF PYRITHIAMINE AND OXYTHIAMINE ON THIAMINE PYROPHOSPHATE SYNTHESIS BY RAT-LIVER THIAMINOKINASE

Incubation mixture: enzyme $0.4 \mathrm{ml}$, ATP $0.002 \mathrm{M}, \mathrm{MgCl}_{2} 0.0066 M$, phosphate buffer $\mathrm{pH} 7.4$ $0.02 M$, thiamine, pyrithiamine and oxythiamine as indicated below, total volume $1.5 \mathrm{ml}$.

Temperature: $37^{\circ} \mathrm{C}$.

\begin{tabular}{|c|c|c|c|c|c|c|}
\hline \multirow{2}{*}{$\begin{array}{l}\text { Enzyme } \\
\text { prep. No. }\end{array}$} & \multirow{2}{*}{$\begin{array}{c}\text { Thiamine } \\
\text { added } \\
(\mu g)\end{array}$} & \multirow{2}{*}{$\begin{array}{c}\text { Pyrithiamine } \\
\text { added } \\
(\mu \mathrm{g})\end{array}$} & \multirow{2}{*}{$\begin{array}{l}\text { Oxythiamine } \\
\text { added } \\
(\mu \mathrm{g})\end{array}$} & \multicolumn{3}{|c|}{$T P P(\mu g)$ found after incubation time } \\
\hline & & & & $I O^{\prime}$ & $25^{\prime}$ & $60^{\prime}$ \\
\hline \multirow[t]{5}{*}{ I } & 5 & - & - & $2 \cdot 3$ & $4 \cdot 3$ & 7.1 \\
\hline & 5 & 6.23 & - & $1 \cdot 3$ & 2.8 & 4.9 \\
\hline & 5 & 62.3 & - & - & 0.8 & I. 7 \\
\hline & 5 & - & $5^{\circ}$ & 2.2 & $4 \cdot 3$ & 6.8 \\
\hline & 5 & 一 & 500 & - & 4.6 & $7 \cdot 0$ \\
\hline \multirow[t]{3}{*}{2} & 10 & - & - & - & - & $7 \cdot 3$ \\
\hline & Io & 12 & - & - & - & 2.6 \\
\hline & IO & 300 & - & - & - & 0.3 \\
\hline
\end{tabular}

DISCUSSION

The experiments described above point to a close resemblance between the thiamine deficiency induced by feeding pyrithiamine together with thiamine and the deficiency resulting from omission of thiamine from the diet.

In both cases we see a rapid disappearance of TPP from the tissues, and a decrease of anaerobic formation of acetoin and consumption of pyruvate in homogenates of breast and heart muscle. In general the decrease of TPP and enzyme activity follows the same time-course during the development of both deficiencies ${ }^{10}$. If anything, the disappearance of TPP after giving pyrithiamine is a little more rapid under our experimental conditions (molar ratio $\mathrm{PT}: \mathrm{T}=5: \mathrm{I}$ ). This is particularly the case in the brain (expts. I and 2). In a thiamine deficiency induced by withholding thiamine TPP disappears much more slowly from this organ than from other organs ${ }^{13}$. The brain thus seems to hold on to its TPP as long as possible.

In conformance with the results of CERECEDO we have found that in vitro the rat-liver thiaminokinase is strongly inhibited by PT. Contrary to the view expressed by Woolley, we believe it is possible that the in vivo effect of PT is also caused by its inhibition of the phosphorylation of thiamine.

Woolley and MerRifield were inclined to discount the possibility of PT acting as an inhibitor of TPP synthesis in vivo, because some of their experiments seemed to be contradictory to this conception.

In the first place they saw that TPP in the liver of mice given a single dose of References $p .344$. 
250 or $500 \mu \mathrm{g} \mathrm{PT}$ and receiving $2 \mu \mathrm{g}$ of T daily was not lower than TPP in the liver of control mice receiving $2 \mu \mathrm{g} \mathrm{T}$ only, at the time that the first-mentioned animals had developed severe deficiency symptoms. In our opinion this is not so surprising, for we found that TPP is only temporarily diminished in several tissues of pigeons after a single big dose of PT. So it could very well be that at the time of investigation the liver TPP of Woolley's mice had more or less regained the level found in the controls. It is possible that the symptoms of deficiency were caused by a depletion of TPP in the brain, so severe that it is followed by secondary irreversible lesions, rendering restoration impossible or at least seriously delayed with this low level of thiamine administration. For we have seen that PT causes a particularly rapid disappearance of TPP from the brain.

In the second place Wooliey observed that very large amounts of PT $(2.5 \mathrm{mg})$ were needed to detect inhibition of the phosphorylation of Io $\mu \mathrm{g} \mathrm{T}$ by I ml chicken blood in vitro. The concentration of $\mathrm{PT}$ in the tissues after oral administration could never attain so high a level in proportion to the concentration of $T$. However, chicken blood is known to contain a phosphatase and this may have obscured Wooliey's results by decomposing part of the TPP formed. The thiaminokinase prepared from rat liver according to LEUTHARDT AND NIELSEN, which we have used for our in vitro experiments, does not contain a phosphatase. As shown in Table VIII, a PT:T ratio of I:I gives about $50 \%$ inhibition, which compares favourably with WoolLEY's observation of approximately $50 \%$ inhibition by a PT:T ratio of $250: \mathrm{I}$ in the chicken blood system. We estimate that a pigeon weighing $400 \mathrm{~g}$ contains in all I-I.5 mg TPP. Although this TPP undergoes a continual and rapid dephosphorylation and rephosphorylation ${ }^{14}$, we do not think that much more than about 5 to $10 \%$ of this amount is ever present as free $T$ in the tissues ${ }^{15}$. Thus at any time, even shortly after feeding, the level of free thiamine in the tissues will be so low, that if we give a daily dose of $623 \mu \mathrm{g}$ PT or a single dose of 2.5 or Io $\mathrm{mg}$ PT, the ratio of PT to $\mathrm{T}$ in the tissues would seem to be quite favourable for an inhibitory action of PT on the phosphorylation of $T$.

Our view that $\mathrm{PT}$ acts by inhibiting phosphorylation of $\mathrm{T}$ to TPP is also supported by the observation that pigeons receiving $623 \mu \mathrm{g}$ PT daily without added thiamine lose their TPP much more rapidly than pigeons on a thiamine- and antivitamin-free diet (expt. 4). This is consistent with an inhibition of the rephosphorylation of $T$ set free by decomposition of endogenous TPP.

Naturally, one could also picture an action of PT through a displacement of TPP on the active sites of enzymes by PTPP. It is possible that some PT is phosphorylated to PTPP in the tissues, but preliminary experiments with rat liver thiaminokinase in vitro gave us the impression that this enzyme phosphorylates $\mathrm{PT}$ much less readily than $\mathrm{T}$. We therefore prefer the conception we have just set forth above.

Administration of oxythiamine does not have nearly such a marked influence on the TPP content of organs of pigeons ${ }^{12}$. This agrees with the observation that OT does not inhibit rat liver thiaminokinase in vitro. As OT does have some effect in vivo, the remaining possibility becomes probable that OT acts after phosphorylation to OTPP as a competitor with TPP for active enzyme sites. The circumstance that the $T$ and OT molecules have identical thiazole parts is in favour of this view. Phosphorylation takes place there, and CERECEDO ${ }^{16}$ found that chloro-OT and bromo-OT, which cannot be phosphorylated, have no antivitamin action.

WOOLLEY AND MERRIFIELD believe that opisthotonus and other typical poly- 
neuritic symptoms of thiamine deficiency, which are also seen after giving PT, are particular exponents of an impairment of a second function of $T$, independent of TPP synthesis. According to these authors, opisthotonus is rarely seen in animals feeding ad libitum, because they eat hardly anything in the later stages of athiaminosis owing to a lack of appetite. On the other hand, opisthotonus would be very frequent in pigeons forcibly fed a carbohydrate-rich thiamine-deficient diet. The demand on free thiamine in the body to form TPP for metabolizing the ingested carbohydrate would then be so great that also the free thiamine in the brain, necessary for preventing opisthotonus, is exhausted to such an extent that this symptom develops.

Our experience does not agree with these observations in all respects. Indeed, we have also rarely seen polyneuritic symptoms in rats feeding ad libitum on a diet poor in thiamine. They die suddenly, showing only anorexia. But if such rats repeatedly receive small doses of thiamine to prolong their survival, convulsions are observed in nearly all of the animals. Pigeons eating washed polished rice (which still contains traces of thiamine) ad libitum invariably show anorexia and a loss of body weight, and, almost without exception, opisthotonus before death. However, when pigeons are given a thiamine-deficient food rich in carbohydrate by stomach tube every day, death is very sudden and opisthotonus rare. But after forced feeding of a deficient diet in which the carbohydrate has been replaced by an isocaloric amount of fat, death is less sudden and opisthotonus is very frequent $\left(G_{R U B E R}{ }^{8}\right)$.

We were at first inclined to correlate the occurrence of opisthotonus with a low level of TPP in the brain at death. GRUBER found a significantly lower amount of TPP in the brain of pigeons dying on a thiamine-deficient diet containing fat instead of carbohydrate, as compared to pigeons dying on a deficient diet rich in carbohydrate. Incidence of opisthotonus was $8 \mathrm{I} \%$ in the first group and II \% in the second group.

However, one can also argue that opisthotonus is observed as the terminal stage of a slowly developing deficiency disease, while it is rarely seen in a rapidly developing deficiency. For in GRUBER's experiments the pigeons receiving fat survived 45 days on average, while the pigeons receiving carbohydrate died after 16 days in the mean (cf. also rats kept alive on small doses of thiamine).

In the experiments with pyrithiamine there is a high incidence of opisthotonus as well as ataxia and convulsions. When Ioo $\mu \mathrm{g}$ T plus $623 \mu \mathrm{g}$ PT are given daily as a supplement to a carbohydrate-rich diet, the survival time of the pigeons is again much longer than on the same diet without thiamine and without PT (average: $>34$ vs. I7 days). Again TPP in the brain is lower at death on the first-mentioned diet (expt. 3). This is in agreement with previous observations. On the other hand, pigeons fed a diet rich in carbohydrate, supplemented with PT only, also show a high incidence of opisthotonus, but die after only 5 days in the mean, and at that time have not yet attained such a low level of TPP in the brain (expt. 4).

This last experiment in particular cautions us that the time has not yet come to attach a causal significance to the concomitant occurrence of polyneuritic symptoms and specific disturbances in thiamine metabolism.

But however this may be, we do not believe there is any need for postulating a second function of thiamine in the nervous system, independent of its phosphorylation to TPP. As a matter of fact we have observed a strong decrease of TPP in the tissues after giving $\mathrm{PT}$ to pigeons, and we have not observed any phenomena that cannot also be induced in another manner, without taking recourse to this antivitamin. Our 
experiments thus give us no reason to believe, as WoOLLEY does, that PT would specifically inhibit a particular function of thiamine in nervous tissue.

\section{ACKNOWLEDGEMENTS}

The author is greatly indebted to Professor H. G. K. Westenbrink and Dr. E. P. STEYN-PARvé for much helpful advice and criticism during the course of this investigation, and to Dr. K. DEY for his collaboration in part of the experiments.

\section{SUMMARY}

I. A study was made of the development of thiamine deficiency in pigeons by feeding the antagonist pyrithiamine together with thiamine, as a supplement to a diet rich in carbohydrate. This deficiency was compared to that induced in the traditional manner by feeding a thiamine-free carbohydrate-rich diet.

2. In both cases a strong decrease of the thiamine pyrophosphate content of various tissues was observed, as well as a decrease in anaerobic formation of acetoin and consumption of pyruvate by homogenates of breast and heart muscle. In most respects there is a close resemblance between the two types of deficiency.

3. The only differences were: (a) after giving pyrithiamine, thiamine pyrophosphate decreases as rapidly in brain as it does in other organs, while this tissue is slower in losing its thiamine pyrophosphate when thiamine is withheld from the diet; (b) after giving pyrithiamine there is a much higher incidence of opisthotonus on the carbohydrate-rich diet than after withholding thiamine. However, it is not yet possible to establish a causal relationship between the occurrence of opisthotonus and the disappearance of thiamine pyrophosphate from the brain.

4. Pyrithiamine strongly inhibits the phosphorylation of thiamine by rat-liver thiaminokinase in vitro.

5. It seems most likely that pyrithiamine will also act in vivo by inhibiting the phosphorylation of thiamine to thiamine pyrophosphate. This gives an adequate explanation of all phenomena observed.

6. There is no necessity for postulating a second specific function of thiamine in the brain, not requiring phosphorylation to thiamine pyrophosphate, a function upon which pyrithiamine would exert a specific action.

\section{REFERENCES}

1 D. W. Wooliey and R. B. Merrifield, Bull. soc. chim. biol., 36 (1954) 1207.

2 D. W. Woolley, J. Biol. Chem., 191 (195I) 43.

${ }^{3}$ H. G. K. Westenbrink and E. P. Steyn-Parvé, Intern. Rev. Vitamin Research, (Intern. Z. Vitaminforsch.), 21 (I950) $46 \mathrm{I}$.

4 W. W. Whsterfeld, J. Biol. Chem., 161 (1945) 495.

s T. E. Friedemann and C. E. Haugen, J. Biol. Chem., I 47 (1943) 415

6 F. Leuthardt and H. Nielsen, Helv. Chim. Acta, 35 (1952) i ig6.

7 B. C. P. Jansen and H. G. K. Westenbrink, Acta Brevia Neerl. Physiol. Pharmacol. Microbiol., 3 (I 933) 9 .

8 M. Gruber, Biochim. Biophys. Acta, 1o (1953) I 36; M. Gruber, Thesis, Utrecht, I952.

9 F. WILcoxon, Biometrics, I (I945) 80; H. B. Mann and D. R. Whitney, Ann. Math. Stat., I 8 (1947) 50 .

10 C. H. Monfoort, Biochim. Biophys. Acta, 16 (1955) 319; C. H. Monfoort, Thesis, Utrecht, I955.

11 L. R. Cerecedo, Am. J. Clin. Nutrition, 3 (1955) 273.

12 E. P. Steyn-Parve, Biochim. Biophys. Acta, I 4 (I954) 440.

13 H. G. K. Westenbrink, Arch. nérl. physiol., I7 (1932) 560.

14 J. E. Vincent, Rec. trav. chim., 76 (I957) 779; K. H. Kiessling, Arkiv Kemi, i I (1957) 451 .

$15 \mathrm{~S}$. Ochoa and R. A. Peters, Biochem. J., 32 (1938) i $501 ; \mathrm{H}$. G. K. Westenbrink and J. Goudsmit, Nature, 142 (1938) I 5 I; H. G. K. Westenbrink and J. Goudsmit, Enzymologia, 5 (1938) 307 ; L. de Caro, G. Rindi, V. Perri and G. Ferrari, Experientia, 13 (I957) r65.

16 L. R. Cerecedo, M. Soodak and A. J. Eusebi, J. Biol. Chem., i 89 (195I) 293. 